\title{
Model Regresi Cox Non Proporsional Hazard dan Aplikasinya pada Data Ketahanan Hidup Pasien Penderita Tuberkulosis di Balai Besar Kesehatan Paru Masyarakat Makassar
}

\author{
Wahidah Sanusi ${ }^{1}$, Alimuddin ${ }^{1}$ dan Andi Diki Nurbaldatun Islam1 ${ }^{\text {, a) }}$ \\ ${ }^{1}$ Jurusan Matematika, FMIPA Universitas Negeri Makassar, 90224 \\ a)e-mail: dikinurbaldatun@gmail.com
}

\begin{abstract}
Abstrak. Jenis penelitian ini adalah merupakan penelitian terapan (applied research) dengan pendekatan kuantitatif yaitu dengan mengambil atau mengumpulkan data yang diperlukan dan menganalisisnya dengan menggunakan model regresi cox non proporsional hazard untuk mengetahui faktor-faktor yang mempengaruhi laju kesembuhan pada penderita tuberkulosis di Balai Besar Kesehatan Paru Masyarakat Makassar. Lama pengobatan pasien penderita tuberkulosis merupakan waktu survival. Sesuai dengan Uji Anderson Darling menggunakan software Minitab 15, maka hasil uji distribusi pada waktu survival dari penderita tuberkulosis berupa distribusi Logistik. Ada beberapa faktor yang diduga mempengaruhi laju kesembuhan pasien seperti umur pasien, jenis kelamin pasien, status merokok pasien, suhu badan pasien, dahak pasien, nafas pasien, keringat pasien, stamina pasien, nafsu makan pasien, dan berat badan pasien. Oleh karena itu, perlu diketahui faktor-faktor apa saja yang signifikan mempengaruhi laju kesembuhan pasien. Dari hasil penelitian menggunakan software SPSS 20, memberikan kesimpulan bahwa faktor-faktor yang mempengaruhi laju kesembuhan pasien penderita tuberkulosis di Balai Besar Kesehatan Paru Masyarakat Makassar adalah nafas pasien, stamina pasien, dan nafsu makan pasien.
\end{abstract}

Kata Kunci: Regresi Cox Non Proporsional Hazard, Distribusi Logistik, Tuberkulosis

\begin{abstract}
This type of research is applied research with a quantitative approach that is to take or collect the necessary data and analyze it by using a model of cox regression models with nonproportional hazard to determine the factors that affect the rate of recovery of tuberculosis patients in Large Hall of Pulmonary Health Makassar Society. Long treatment of patients tuberculosis is the time of survival. In accordance with the Anderson Darling test using the software Minitab 15, the test results on the distribution of survival time of tuberculosis patients is Logistic Distribution. There are many factors that will affect the rate of recovery of patients such as age of the patients, gender of the patients, smoking status of the patients, body temperature of the patients, sputum of the patients, breath of the patients, sweat of the patients, stamina of the patients, appetite of the patients, and weight of the patients. Therefore, it is important to know what the factors most affect the rate of recovery of tuberculosis patients. From the results of the research using software SPSS 20, give conclusion that factors affecting of time recovery of tuberculosis patients in Large Hall of Pulmonary Helath Makassar Society are breath of the patients, stamina of the patients, and appetite of the patients.

Keywords: Cox Regression Models With Non Proportional Hazard, Logistic Distribution, Tuberculosis
\end{abstract}

\section{PENDAHULUAN}

Analisis survival adalah metode statistika yang digunakan untuk menganalisis data dimana variabel outputnya berupa lama waktu hingga terjadinya sebuah peristiwa dengan melihat 
variabel-variabel yang menjadi perhatian. Regresi yang sering digunakan untuk menganalisis data survival ada bermacam-macam, yaitu regresi parametrik, regresi non parametrik, dan regresi semi parametrik. Regresi parametrik memiliki syarat bahwa bahwa baseline survival mengikuti suatu distribusi tertentu. Jika syarat tidak dipenuhi, dapat digunakan regresi non parametrik. Jika baseline hazardnya mengikuti model non parametrik sedangkan variabel-variabel independennya mengikuti model parametrik maka digunakan regresi semi parametrik, dimana yang sering dikenal adalah regresi cox. Analisis regresi cox merupakan analisis yang digunakan untuk menganalisa data waktu kejadian dan untuk mengetahui hubungan waktu kejadian dengan salah satu variabel bebasnya. Regresi Cox pertama kali dikembangkan oleh Cox pada tahun 1972. Regresi ini lebih populer digunakan dalam penelitian tentang data kesehatan, data ekonomi, yang variabel responnya berupa waktu (hari, bulan, tahun). Misalnya data tentang waktu pasien menderita penyakit tertentu, dimana dimulai dari awal masuk rumah sakit sampai terjadi kejadian tertentu, seperti kematian, sembuh atau kejadian khusus lainnya (Ernawatiningsih \& Purhadi, 2012)..

Bentuk umum regresi cox adalah $h\left(t \mid Z_{j}\right)=h_{0}(t) \exp \left(\beta Z_{j}\right)$, dimana $Z_{j}$ adalah nilai variabel untuk individu $k e-\mathrm{j}, \mathrm{h}_{0}(\mathrm{t})$ adalah fungsi baseline hazard dan $\beta$ adalah hubungan antara variabel bebas dengan besarnya nilai hazard. Penggunaan regresi Cox harus memenuhi proportional hazard. Proporsional hazard adalah perbandingan kecepatan terjadinya suatu kejadian antar kelompok setiap saat adalah sama. Jika asumsi ini tidak terpenuhi dalam memodelkan regresi Cox, berarti komponen linear yang membentuk model dalam berbagai waktu tidak sesuai, akibatnya pemodelan regresi Cox tidak tepat (Kleinbaum \& Klein, 2005). Cara lain yang dapat digunakan untuk mengatasi nonproportional hazard adalah stratified proportional hazard. Tujuan dari analisis stratified adalah untuk menguji hipotesis apakah model regresi tepat untuk kelompok yang berbeda atau tidak, menjelaskan model regresi Stratified Cox dapat digunakan untuk menganalisis kejadian berulang tidak identik (Habriantho, 2016).

Tuberkulosis (TB) adalah penyakit menular langsung yang disebabkan oleh kuman Mycobacterium tuberculosis, sebagian besar kuman ini menyerang paru, tetapi juga dapat menyerang organ tubuh lainnya.TB paru merupakan penyakit kronis (menahun) yang telah lama dikenal oleh masyarakat luas dan ditakuti karena menular. Cara penularan TB yaitu salah satunya melalui udara atau bercak lendir atau dahak penderita (Wikipedia, 2014). Khusus di kota Makassar, berdasarkan data yang diperoleh dari Bidang Bina Pencegahan Penyakit dan Penyehatan Lingkungan Dinas Kesehatan Kota Makassar, angka penemuan penderita baru TB Paru BTA (+) tahun 2013 sebanyak 72,44\%, jumlah ini meningkat dari tahun 2012. Jika dibandingkan pada tahun 2013 sebesar 72,44\% melebihi target sebesar 70\%. Proses penemuan penyakit TB dilakukan oleh pengelola TB masing-masing puskesmas di kota Makassar melalui pelacakan (Dinkes Makassar, 2013). Analisis model regresi cox biasanya digunakan di bidang kesehatan. Pada penelitian ini regresi cox digunakan untuk mengetahui faktor-faktor apa saja yang signifikan yang mempengaruhi laju kesembuhan pasien penderita tuberkulosis di Balai Besar Kesehatan Paru Masyarakat Makassar pada Periode Desember 2015 - Maret 2016.

\section{Analisis Survival}

Analisis survival adalah teknik statistik yang digunakan untuk menganalisis data yang bertujuan untuk mengetahui hasil dari variabel yang mempengaruhi suatu awal kejadian sampai akhir kejadian, contohnya waktu yang dicatat dalam hari, minggu, bulan, atau tahun. Untuk kejadian awal contohnya awal pasien terjangkit penyakit dan untuk kejadian akhir contohnya kematian pasien dan kesembuhan pasien (Kleinbaum \& Klein, 2011).

Menurut Klein \& Moeschberger (1997), ada beberapa tujuan analisis survival:

1. Mengestimasi/memperkirakan dan menginterpretasikan fungsi survival dan fungsi hazard.

2. Membandingkan fungsi survival dan fungsi hazard pada dua atau lebih kelompok.

3. Menilai hubungan variabel-variabel independen dengan survival waktu ketahanan. 


\section{Survival Time}

Dalam analisis survival, variabel respon yang diperhatikan adalah waktu sampai munculnya suatu kejadian, sehingga analisis survival seringkali disebut sebagai analisis waktu kejadian (time to event). Waktu suatu objek telah bertahan selama periode pengamatan atau sampai muncul suatu kejadian yang diinginkan disebut survival time atau failure time. Oleh karena itu, survival time adalah suatu variabel yang mengukur waktu dari sebuah titik awal tertentu (misalnya, waktu di mana suatu perlakuan/pengobatan dimulai) sampai dengan sebuah titik akhir yang akan diperhatikan (misalnya, waktu kesembuhan pada penderita Tuberkulosis). Data survival dikumpulkan dalam suatu periode waktu terbatas, dan sebagai konsekuensinya bisa saja data yang diperoleh tidak mencakup total waktu bertahan seseorang. Artinya saat kita mengambil data survival masih ada kemungkinan seseorang belum mengalami kejadian tertentu. Misalnya seseorang belum menunjukkan respon dari hasil terapinya tetapi data waktu bertahannya sudah dicatat karena penelitian dihentikan. Hal inilah yang kemudian dalam analisis survival disebut dengan data tersensor (Rahayu, dkk, 2012).

\section{Fungsi Distribusi Kumulatif}

Jika T merupakan variabel random dari waktu hidup suatu individu dalam interval $[0, \infty)$ maka fungsi distribusi kumulatif $F(t)$ untuk distribusi kontinu dengan fungsi densitas peluang $\mathrm{f}(\mathrm{t})$ dinyatakan pada persamaan (1) sebagai berikut (Sari, 2011):

$$
F(t)=\int_{0}^{t} f(t) d t, \text { untuk } t>0
$$

Fungsi Ketahanan Hidup (Fungsi Survival)

Fungsi ketahanan hidup adalah peluang suatu individu akan beroperasi dengan baik untuk periode waktu tertentu di bawah kondisi operasi yang ditentukan. Ketahanan hidup dapat digunakan sebagai pengukur keberhasilan suatu sistem dalam menjalankan fungsinya dengan baik. Misalkan $\mathrm{n}_{0}$ adalah banyaknya individu penderita penyakit tertentu. Selama interval waktu $(\mathrm{t}, \mathrm{t}+\Delta \mathrm{t})$, diamati banyaknya individu yang gagal akibat penyakit tersebut $n_{f}(t)$, sehingga $\left[n_{f}(t)+n_{s}(t)=\right.$ $\mathrm{n}_{0}$ ]. Jika ketahanan hidup didefinisikan sebagai fungsi peluang kumulatif seorang pasien bertahan hidup lebih dari waktu $t$, dengan $t>0$, maka fungsi ketahanan hidup $\mathrm{S}(\mathrm{t})$ menurut Hanni \& Wuryandari (2013) adalah:

$$
S(t)=1-F(t)=1-\int_{0}^{t} f(t) d t
$$

\section{Fungsi Densitas Peluang}

Waktu tahan hidup $T$ mempunyai fungsi densitas peluang yang dinotasikan dengan $f(t)$ dan didefinisikan sebagai peluang kegagalan suatu individu pada interval $(t, t+\Delta t)$ per satuan waktu. Fungsi densitas peluang menurut Hanni \& Wuryandari (2013) sdinyatakan pada persamaan (3)

$$
f(t)=\lim _{\Delta t \rightarrow 0}\left[\frac{P(\text { objek gagal pada }(t, t+\Delta))}{\Delta t}\right]=\lim _{\Delta t \rightarrow 0}\left[\frac{P(t<T<t+\Delta t}{\Delta t}\right]
$$

\section{Fungsi Hazard}

Fungsi kegagalan dari waku tahan hidup $\mathrm{T}$ dinotasikan dengan $\mathrm{h}(\mathrm{t})$ dan didefinisikan sebagai peluang suatu individu gagal di dalam interval waktu $(t, t+\Delta t)$ dengan diketahui bahwa individu tersebut telah hidup selama waktu t. Fungsi hazard menurut Hanni \& Wuryandari (2013) dinyatakan pada persamaan (4) 


$$
h(t)=\frac{f(t)}{1-F(t)}, \text { dengan syarat } \mathrm{F}(\mathrm{t}) \neq 1
$$

Selanjutnya untuk fungsi kegagalan kumulatif didefinisikan dengan peluang kegagalan dari interval 0 hingga t yang dinyatakan dengan persamaan (5)

$$
H(t)=\int_{0}^{t} h(t) d t
$$

\section{Pengujian Distribusi Data}

Pendugaan distribusi digunakan pada data survival yang dalam penelitian ini adalah data lama pengobatan pasien Tuberkulosis hingga dinyatakan sembuh. Pendugaan distribusi dilakukan dengan statistik uji Anderson-Darling untuk mengetahui distribusi data survival yang paling sesuai. Persamaan statistik uji Anderson-Darling adalah sebagai berikut (Fa'rifah \& Purhadi, 2012):

$$
A^{2}=-n-\frac{1}{n} \sum_{i=1}^{n}(2 i-1)\left[\left(\ln F\left(t_{i}\right)+\ln \left(1-F\left(t_{n+1-i}\right)\right)\right]\right.
$$

dimana:

$\mathrm{F}=$ Fungsi distribusi kumulatif dari distribusi tertentu

$\mathrm{t}_{\mathrm{i}}=$ Data waktu survival.

Dalam hal ini pendugaan distribusi yang sesuai dipilih berdasarkan nilai Anderson-Darling terkecil.Jika $\mathrm{A}^{2}>\mathrm{A}_{\text {tabel }}^{2}$ maka menolak $\mathrm{H}_{0}$, sehingga data tidak mengikuti sebaran distribusi normal.

\section{Model Regresi Cox}

Cox proporsional hazard ialah pemodelan yang digunakan dalam analisis survival yang merupakan model semi parametrik. Regresi cox proportional hazard ini digunakan bila outcome yang diobservasi adalah panjang waktu suatu kejadian. Pada mulanya pemodelan ini digunakan pada cabang statistika khususnya biostatistika yaitu digunakan untuk menganalisis kematian atau harapan hidup seseorang. Namun seiring perkembangan zaman pemodelan ini banyak dimanfaatkan di berbagai bidang. Diantaranya bidang akademik, kedokteran, sosial, science,teknik, pertanian dan sebagainya (Sari, 2011). Melalui model Cox dapat dilihat hubungan antara variabel independen terhadap variabel terikat yaitu waktu survival melalui hazard nya. Risiko kematian individu pada waktu tertentu bergantung pada nilai $\mathrm{x}_{1}, \mathrm{x}_{2}, \ldots, \mathrm{x}_{\mathrm{p}}$ dari $\mathrm{p}$ variabel bebas $\mathrm{X}_{1}, \mathrm{X}_{2}, \ldots, \mathrm{X}_{\mathrm{p}}$. Himpunan nilai variabel bebas pada model cox dipresentasikan oleh vektor $\mathrm{x}$, sehingga $\mathrm{x}=\left(\mathrm{x}_{1}, \mathrm{x}_{2}, \ldots \ldots, \mathrm{x}_{\mathrm{p}}\right)$. Diasumsikan merupakan variabel bebas yang independen terhadap waktu. Model regresi cox dapat dinyatakan pada persamaan (7)

$$
h(t, x)=h_{0}(t) \exp \left(\beta_{1} x_{1}+\beta_{2} x_{2}+\ldots+\beta_{p} x_{p}\right)
$$

dimana:

t : Waktu survival

$\mathrm{h}_{0}(\mathrm{t}) \quad$ : Fungsi baseline hazard

$\beta_{1}, \beta_{2}, \ldots, \beta_{\mathrm{p}}$ : Parameter regresi

$\mathrm{x}_{1}, \mathrm{x}_{2}, \ldots, \mathrm{x}_{\mathrm{p}}$ : Nilai dari variabel bebas $\mathrm{X}_{1}, \mathrm{X}_{2}, \ldots, \mathrm{X}_{\mathrm{p}}$ 


\section{Model Regresi Cox Non Proporsional Hazard}

Model regresi Cox bergantung pada hazard yang proporsional, dan efek dari kovariat yang diberikan konstan dari waktu ke waktu, ini sangat penting untuk memastikan bahwa kovariat memenuhi asumsi proporsionalitas. Jika asumsi ini tidak terpenuhi, maka model regresi Cox tidak terpenuhi dan dibutuhkan penyelesaian seperti Model Cox Stratifikasi atau Model Cox Extended. Model cox stratifikasi adalah model yang didapatkan dengan memodifikasi model cox proportional hazard. Modifikasi dilakukan dengan mengontrol covariate yang tidak memenuhi asumsi PH. Pengontrolan ini dilakukan dengan cara menstratifikasi covariate tersebut. Misalkan, ada sebanyak $m$ covariate. Misalkan pula tidak ada interaksi antar covariate. Model Cox PH yang terbentuk adalah

$$
h(t, X)=h_{0}(t) \exp \left[\beta_{1} X_{1}+\cdots+\beta_{k} X_{k}+\beta_{k+1} X_{k+1}+\cdots+\beta_{m} X_{m}\right]
$$

Dari $m$ covariate tersebut, misalkan ada sebanyak $k$ covariate yang memenuhi asumsi PH dan ada $p$ covariate yang tidak memenuhi asumsi $\mathrm{PH}$, di mana $p=m-k$. Tanpa menghilangkan sifat keumuman, misalkan covariate yang tidak memenuhi asumsi $\mathrm{PH}$ tersebut adalah $X_{k+1}, X_{k+2}, \ldots, X_{m}$ dan sesudah dilakukan stratifikasi variabel terbentuk $k^{*}$ strata (Kleinbaum \& Klein, 2005).

\section{Odds Rasio}

Laju kesembuhan pasien dapat dilihat dari nilai hazard rasio atau odds rasio. Odds rasio merupakan suatu ukuran yang digunakan untuk mengetahui tingkat risiko (kecendrungan) yaitu perbandingan antara Odd individu dengan kondisi variabel predictor X pada kategori sukses dengan kategori gagal (Hosmer \& Lemeshow, 1997). Odds rasio untuk individu dengan $\mathrm{x}=2$ dibanding $\mathrm{x}=1$ adalah:

$$
O R=\frac{h_{0}(t \mid \mathrm{x}=2)}{h_{0}(t \mid \mathrm{x}=1)}=\frac{h_{0}(t) e^{2 \beta}}{h_{0}(t) e^{\beta}}=e^{\beta}
$$

Sehingga diperoleh nilai OR yang artinya bahwa tingkat kecepatan terjadinya failure event pada individu dengan kategori $\mathrm{x}=2$ adalah sebesar $\mathrm{e}^{\beta}$ kali tingkat kecepatan terjadinya risiko terjadinya peristiwa failure event pada individu dengan kategori $\mathrm{x}=1$.

\section{Pengujian Signifikansi Parameter Model}

Menurut Febriyanti, Yozza \& Rahmi (2013) dan Cahyani, Subanti \& Widyaningsih (2014), pada model dilakukan uji signifikansi parameter yang meliputi uji bersamaan (serentak) dan uji individu.

\section{Uji Signifikansi Bersamaan (Serentak)}

1. Uji Hipotesis:

$$
\begin{aligned}
& H_{0}: \beta_{1}=\beta_{2}=\cdots=\beta_{K}=0 \\
& (10) \\
& H_{1}: a d a \beta_{k} \neq 0, k=1,2, \ldots, K
\end{aligned}
$$

2. Daerah penolakan

$H_{0}$ ditolak jika $G \geq X^{2}(\alpha ; d b=p)$ atau p-value $\leq \alpha=0,05$, dimana $=-2\left[\ln L(0)-\ln L\left(\beta_{k}\right)\right], p$ : banyaknya variabel bebas

3. Jika $H_{0}$ ditolak maka $\beta_{i} \neq 0$ mengindikasikan bahwa variabel bebas berpengaruh terhadap waktu survival (variabel dependen). 
Uji Signifikansi Individu

4. Merumuskan Hipotesis:

$H_{0}: \beta_{i}=0$ (variabel bebas tidak signifikan)

$H_{1}: \beta_{i} \neq 0$ (variabel bebas signifikan)

5. Kriteria keputusan

Tolak $H_{0}$ jika $W>X_{\left(1 ; \frac{\alpha}{2}\right)}^{2}$ atau sig $<\alpha=0,05$, yang artinya variabel bebas signifikan di dalam model.

6. Kesimpulan:

Jika $H_{0}$ ditolak maka $\beta_{i} \neq 0$ mengindikasi bahwa variabel bebas berpengaruh terhadap waktu survival (variabel dependen).

\section{Pengujian Asumsi Proporsional Hazard}

Proporsional Hazard (PH) artinya perbandingan terjadinya suatu kejadian antar kelompok setiap saat adalah sama. Asumsi proporsiona hazard dapat diketahui dengan membuat kurva kapplan - meier. Metode lain untuk menguji asumsi proporsional hazard adalah dengan membuat kurva ln-ln survival dan global test (Nurhaniah, 2015). Asumsi Proportional Hazard terpenuhi apabila :

7. Garis survival pada kurva Kapplan - Meier tidak saling berpotongan

8. Garis survival pada ln-ln survival tidak saling berpotongan

9. Nilai $p$ pada uji global test lebih besar dari 0,05

\section{Tuberkulosis}

Tuberkulosis (Tuberculosis, disingkat Tbc), atau Tb (singkatan dari "Tubercle bacillus") merupakan penyakit menular yang umum, dan dalam banyak kasus bersifat mematikan. Penyakit ini disebabkan oleh berbagai strain mikobakteria, umumnya Mycobacterium tuberculosis (disingkat "MTb" atau "MTbc"). Tuberkulosis biasanya menyerang paru-paru, namun juga bisa berdampak pada bagian tubuh lainnya. Tuberkulosis menyebar melalui udara ketika seseorang dengan infeksi TB aktif batuk, bersin, atau menyebarkan butiran ludah mereka melalui udara. Infeksi TB umumnya bersifat asimtomatik dan laten. Namun hanya satu dari sepuluh kasus infeksi laten yang berkembang menjadi penyakit aktif. Bila Tuberkulosis tidak diobati maka lebih dari $50 \%$ orang yang terinfeksi bisa meninggal. Adapun gejala-gejala apabila seseorang menderits penyakit tuberkulosis adalah penurunan nafsu makan dan berat badan, mengalami mudah lelah, demam tidak terlalu tinggi yang berlangsung lama, mengalami sesak nafas, dahak bercampur darah, dan berkeringat tanpa sebab pada malam hari.

\section{METODE PENELITIAN}

Penelitian yang dilakukan merupakan penelitian terapan (applied research) dengan pendekatan kuantitatif yaitu dengan mengambil atau mengumpulkan data yang diperlukan dan menganalisisnya dengan menggunakan model regresi Cox Nonproporsional Hazard untuk mengetahui apakah ada pengaruh signifikan faktor-faktor yang diduga mempengaruhi laju kesembuhan penyakit Tuberkulosis di Balai Besar Kesehatan Paru Masyarakat Makassar periode Desember 2015 - Maret 2016. Data yang digunakan dalam penelitian ini adalah data sekunder penderita tuberkulosis di Balai Besar Kesehatan Paru Masyarakat Makassar. Jumlah data yang diperoleh sebesar 41 data. 


\section{Variabel Penelitian}

10. Variabel dependen: waktu survival (lama pengobatan pasien tuberkulosis mulai pengobatan sampai dinyatakan sembuh)

11. Variabel independen:

TABEL 1. Variabel Independen Penelitian

\begin{tabular}{|c|c|c|}
\hline Variabel & Keterangan & Kategori \\
\hline $\mathrm{X}_{1}$ & Usia & \\
\hline $\mathrm{X}_{2}$ & Jenis Kelamin Pasien & $\begin{array}{l}\text { 1: Laki-Laki } \\
\text { 2: Perempuan }\end{array}$ \\
\hline$X_{3}$ & Merokok & $\begin{array}{c}\text { 1: Merokok } \\
\text { 2: Tidak Merokok }\end{array}$ \\
\hline $\mathrm{X}_{4}$ & Suhu Badan Pasien & $\begin{array}{l}\text { 1: Tinggi } \\
\text { 2: Rendah }\end{array}$ \\
\hline $\mathrm{X}_{5}$ & Dahak Pasien & $\begin{array}{c}\text { 1: Dahak Bercampur Darah } \\
\text { 2: Dahak Tidak Bercampur Darah }\end{array}$ \\
\hline $\mathrm{X}_{6}$ & Nafas Pasien & $\begin{array}{c}\text { 1: Sesak Nafas } \\
\text { 2: Tidak Sesak Nafas }\end{array}$ \\
\hline $\mathrm{X}_{7}$ & Keringat Pasien & $\begin{array}{c}\text { 1: Berkeringat Pada Malam Hari } \\
\text { 2: Tidak Berkeringat Pada Malam Hari }\end{array}$ \\
\hline $\mathrm{X}_{8}$ & Stamina Pasien & $\begin{array}{c}\text { 1: Mudah Lelah } \\
\text { 2: Tidak Mudah Lelah }\end{array}$ \\
\hline $\mathrm{X}_{9}$ & Nafsu Makan Pasien & $\begin{array}{c}\text { 1: Nafsu Makan Berkurang } \\
\text { 2: Nafsu Makan Tidak Berkurang }\end{array}$ \\
\hline $\mathrm{X}_{10}$ & Berat Badan Pasien & $\begin{array}{c}\text { 1: Berat Badan Menurun } \\
\text { 2: Berat Badan Tidak Menurun }\end{array}$ \\
\hline
\end{tabular}

\section{HASIL DAN PEMBAHASAN}

\section{Analisis Statistika Deskriptif}

TABEL 2. Analisis Statistika Deskriptif Terhadap Variabel Data Kategorik

\begin{tabular}{lcc}
\hline Variabel Independen & Kategori & Persentase \\
\hline \multirow{2}{*}{ Jenis Kelamin Pasien } & Laki-Laki & $63,40 \%$ \\
& Perempuan & $36,60 \%$ \\
\hline \multirow{2}{*}{ Merokok Pasien } & Merokok & $43,90 \%$ \\
& Tidak Merokok & $56,10 \%$ \\
\hline \multirow{2}{*}{ Suhu Badan Pasien } & Tinggi & $95,10 \%$ \\
\hline Dahak Pasien & Rendah & $4,90 \%$ \\
\hline
\end{tabular}


JMathCoS 1(1) 2018, hal. 46 - 61

\begin{tabular}{lcc}
\hline & Dahak Tidak Bercampur Darah & $9,80 \%$ \\
\hline \multirow{2}{*}{ Nafas Pasien } & Sesak Nafas & $48,80 \%$ \\
& Tidak Sesak Nafas & $51,20 \%$ \\
\hline \multirow{2}{*}{ Keringat Pasien } & Berkeringat Pada Malam Hari & $61 \%$ \\
& Tidak Berkeringat Pada Malam Hari & $39 \%$ \\
\hline \multirow{2}{*}{ Stamina Pasien } & Mudah Lelah & $58,50 \%$ \\
& Tidak Mudah Lelah & $41,50 \%$ \\
\multirow{2}{*}{ Nafsu Makan Pasien } & Nafsu Makan Berkurang & $51,20 \%$ \\
& Nafsu Makan Tidak Berkurang & $48,80 \%$ \\
\hline \multirow{2}{*}{ Berat Badan Pasien } & Berat Badan Menurun & $56,10 \%$ \\
& Berat Badan Tidak Menurun & $43,90 \%$ \\
\hline
\end{tabular}

TABEL 3. Analisis Statistika Deskriptif Terhadap Variabel Data Kontinu

\begin{tabular}{lccccc}
\hline \multicolumn{1}{c}{ Variabel } & Min & Maks & Rata-Rata & $\begin{array}{c}\text { Standar } \\
\text { Deviasi }\end{array}$ & Varians \\
\hline Usia (Tahun) & 2 & 67 & 30,27 & 18,523 & 343,101 \\
Lama Pengobatan (Hari) & 120 & 220 & 163,88 & 15,560 & 242,110 \\
\hline
\end{tabular}

Berdasarkan TABEL 2 Karakteristik pasien penderita Tuberkulosis adalah memiliki rata-rata lama pengobatan selama 163 hari dan memiliki usia rata-rata 30 tahun.

\section{Uji Kesesuaian Distribusi Lama Pengobatan Pasien Penderita Tuberkulosis}

Pengujian distribusi data dilakukan dengan menggunakan pendekatan Anderson Darling, sebab Anderson Darling menjadi metode pengujian distribusi. Suatu data dikatakan mengikuti distribusi Logistik ketika nilai Anderson Darling $\left(A^{2}\right)$ yang diperoleh adalah yang terkecil dibandingkan nilai Anderson Darling pada distribusi yang lain. Jika Anderson Darling $\left(A^{2}\right)$ yang diperoleh adalah yang terkecil dibandingkan dengan nilai Anderson Darling pada distribusi yang lain, maka gagal tolak hipotesis awal $\left(\mathrm{H}_{0}\right)$. Hasil pengujian distribusi variabel terikat dengan hipotesis yang digunakan adalah sebagai berikut:

$\mathrm{H}_{0}$ : Waktu survival mengikuti distribusi Logistik

$\mathrm{H}_{1}$ : Waktu survival tidak mengikuti distribusi Logistik

TABEL 4. Hasil Uji Kesesuaian Distribusi Lama Pengobatan Pasien Penderita Tuberkulosis

\begin{tabular}{lcc}
\hline \multicolumn{1}{c}{ Distribusi } & Anderson Darling & p-value \\
\hline Normal & 1,352 & $<0,005$ \\
Lognormal & 1,445 & $<0,005$ \\
Exponential & 15,904 & $<0,003$ \\
Weibull & 2,568 & $<0,0010$ \\
Gamma & 1,358 & $<0,005$ \\
Logistic & 0.626 & 0,065 \\
Loglogistic & 0,718 & 0,036 \\
\hline
\end{tabular}


Berdasarkan nilai Anderson Darling tersebut, maka distribusi yang sesuai adalah distribusi Logistik. Fungsi kepadatan peluang (fkp) dari distribusi Logistik diberikan pada persamaan (12)

$$
f(t)=\frac{e^{-\frac{t-\alpha}{\beta}}}{\beta\left(1+e^{-\frac{t-\alpha}{\beta}}\right)^{2}} \text { untuk } \mathrm{t}>0, \alpha>0, \text { dan } \beta>0
$$

dimana:

$\mathrm{t}$ : Data waktu survival

$\beta$ : Parameter Skala

$\alpha$ : Parameter Lokasi

\section{Estimasi Parameter Distribusi Logistik}

Jika data waktu survival mengikuti sebaran Logistik maka fungsi $f(t)$ merupakan fungsi kepadatan peluang dari distribusi logistik. Sehingga bentuk umum dari fungsi kepadatan peluang distribusi logistik pada persamaan (12). Menurut Kapadia, Chan \& Moye (2005), nilai $\mu$ dan $\sigma^{2}$ distribusi logistik, ditunjukkan masing-masing oleh persamaan (13) dan (14)

$$
\begin{gathered}
\mu=\alpha \\
\sigma^{2}=\frac{\pi^{2} \beta^{2}}{3}
\end{gathered}
$$

Berdasarkan metode momen, maka estimasi untuk parameter $\hat{\alpha}$ dan $\hat{\beta}$ masing-masing adalah $\hat{\alpha}=$ $\bar{t}$ dan $\hat{\beta}=\sqrt{\frac{\sigma^{2} 3}{\pi^{2}}}$. Selanjutnya,nilai rata-rata $(\mu)$ dan variansi $\left(s^{2}\right)$ dari data waktu survival atau lama pengobatan pasien penderita tuberkulosis digunakan untuk menentukan nilai estimasi $\hat{\alpha}$ dan $\hat{\beta}$.

Sehingga fungsi hazard kumulatif distribusi logistik yang merupakan fungsi dari baseline hazard pada persamaan (15) yaitu:

$$
h_{o}(t)=H(t)=\frac{\frac{1}{8,578} \frac{e^{-\frac{t-163,88}{8,578}}}{\left(1+e^{-\frac{t-163,88}{8,578}}\right)^{2}}}{1-\left(-\frac{1}{8,578+8,578 e^{-\frac{t-163,88}{8,578}}}\right)}
$$

\section{Pemilihan Model Regresi Cox}

Pemilihan model regresi cox yang cocok diperoleh model dengan $p$-value terbesar dari setiap langkah. Proses pengeluaran variabel independen berhenti pada langkah ke delapan karena $\mathrm{G}_{8} \geq$ $\lambda_{(0,05: 2)}^{2}$ atau $p$-value $<0,05$ untuk semua signifikansi variabel. Dengan bantuan software SPSS diperoleh estimasi parameter dengan metode breslow untuk setiap variabel data penderita pasien tuberkulosis pada TABEL 5. 
TABEL 5. Estimasi Parameter Model Cox Dengan Mengasumsikan Semua Variabel Berpengaruh

\begin{tabular}{lcccc}
\hline \multicolumn{1}{c}{ Variabel } & Koef & Exp(Koef) & SE & $p$-value \\
\hline Umur & 0,008 & 1,008 & 0,014 & 0,576 \\
JenisKelamin & $-0,001$ & 0,999 & 0,531 & 0,999 \\
Merokok & $-0,213$ & 0,808 & 0,646 & 0,742 \\
SuhuBadan & $-0,162$ & 0,851 & 1,285 & 0,900 \\
Dahak & 0,595 & 1,813 & 1,133 & 0,600 \\
Nafas & 1,138 & 3,121 & 0,530 & 0,032 \\
Keringat & 0,445 & 1,560 & 0,418 & 0,287 \\
Stamina & 1,083 & 2,954 & 0,437 & 0,013 \\
NafsuMakan & 0,863 & 2,370 & 0,500 & 0,084 \\
BeratBadan & $-0,299$ & 0,742 & 0,407 & 0,462 \\
\hline
\end{tabular}

Sehingga diperoleh estimasi model cox pada persamaan (19)

$$
\begin{aligned}
& h(t, X)=h_{0}(t) \exp \left(0,008 X_{1}-0,001 X_{2}-0,213 X_{3}-0,162 X_{4}+0,595 X_{5}+1,138 X_{6}+\right. \\
& \left.0,445 X_{7}+1,083 X_{8}+0,863 X_{9}-0,299 X_{10}\right)
\end{aligned}
$$

Untuk mengetahui apakah model pada persamaan (16) sudah tepat, maka dilakukan uji partial likelihood ratio sebagai berikut:

- Hipotesis

- $H_{0}: \beta_{1}=\beta_{2}=\beta_{3}=\beta_{4}=\beta_{5}=\beta_{6}=\beta_{7}=\beta_{8}=\beta_{9}=\beta_{10}=0$

- (variabel $X_{1}, X_{2}, X_{3} X_{4}, X_{5}, X_{6}, X_{7}, X_{8}, X_{9}, X_{10}$ tidak berpengaruh dalam model)

- $H_{1}: \exists \beta_{i} \neq 0, i=1,2,3,4,5,6,7,8,9,10$

- (variabel $X_{1}, X_{2}, X_{3} X_{4}, X_{5}, X_{6}, X_{7}, X_{8}, X_{9}, X_{10}$ berpengaruh dalam model)

- Daerah penolakan: $H_{0}$ ditolak jika $G \geq \chi_{(0,05 ; 9)}^{2}$ atau $p$ value $<0,05$,

- $\operatorname{dimana} G=-2\left(\ln L_{R}-\ln L_{F}\right)$

- Perhitungan:

- Dari hasil perhitungan menggunakan software SPSS diperoleh nilai p-value untuk langkah 1 adalah 0,295 dan nilai -2 log likelihood untuk model Cox tanpa variabel bebas (model null) yaitu $\ln L_{R}=-210,073$ dan nilai $-2 \log$ likelihood untuk model Cox yaitu $\ln L_{F}=$ $-198,432$. Sehingga diperoleh perhitungan sebagai berikut:

$$
G_{(1)}=23,282
$$

- $\quad$ Karena $G_{(1)} \geq \chi_{(0,05: 9)}^{2}=16,9$ sehingga $H_{0}$ ditolak dan dapat disimpulkan bahwa semua variabel bebas berpengaruh dalam model

TABEL 6. Estimasi Parameter Model Cox Terbaik Dengan Eliminasi Backward

\begin{tabular}{lcccc}
\hline \multicolumn{1}{c}{ Variabel } & Koef & SE & p-value & Exp(Koef) \\
\hline Nafas Pasien & 1,027 & 0,481 & 0,033 & 2,794 \\
Stamina Pasien & 0,942 & 0,402 & 0,019 & 2,564 \\
Nafsu Makan Pasien & 0,891 & 0,420 & 0,034 & 2,438 \\
\hline
\end{tabular}

Berdasarkan hasil dari eliminasi backward didapatkan tiga variabel terpilih yang masuk dalam model terbaik Cox yaitu nafas pasien, stamina pasien, dan nafsu makan pasien. Tabel 6 menampilkan hasil estimasi parameter model terbaik Cox berdasarkan hasil eliminasi backward. Model Cox berdasarkan hasil eliminasi backward pada (20) sebagai berikut: 


$$
h(t, X)=h_{0}(t) \exp \left(1,027 X_{6}+0,942 X_{8}+0,891 X_{9}\right)
$$

\section{Pengujian Signifikansi Parameter Model}

Untuk mengetahui variabel-variabel yang berpengaruh signifikan dalam pembentukan model regresi Cox, maka dilakukan pengujian signifikansi parameter pada tiga variabel yang telah masuk dalam persamaan diatas yaitu nafas pasien, stamina pasien, dan nafsu makan pasien. Dari hasil uji wald pada tabel 7 dibawah ini, menunjukkan bahwa tiga variabel tidak dapat berpengaruh secara individu terhadap waktu survival. Jika dibandingkan dengan Tabel 6 yang memperlihatkan hubungan secara bersama-sama dari variabel nafas pasien, stamina pasien, dan nafsu makan pasien terhadap waktu survival, maka model yang sesuai adalah model yang melibatkan ketiga variabel tersebut secara bersama-sama

TABEL 7. Hasil Pengujian Parameter Secara Parsial Dengan Uji Wald

\begin{tabular}{lcccccl}
\hline \multicolumn{1}{c}{ Variabel } & Koef & SE & W & $\chi_{(\mathbf{0}, 05: 1)}^{2}$ & p-value & \multicolumn{1}{c}{ Keputusan } \\
\hline Nafas Pasien & 0,173 & 0,337 & 0,263 & 3,840 & 0,608 & $H_{0}$ diterima \\
Stamina Pasien & 0,596 & 0,349 & 2,920 & 3,840 & 0,087 & $H_{0}$ diterima \\
Nafsu Makan & 0,433 & 0,331 & 1,714 & 3,840 & 0,191 & $H_{0}$ diterima \\
Pasien & & & & & & \\
\hline
\end{tabular}

\section{Pemilihan Model Terbaik Model Regresi Cox}

Berdasarkan nilai $G_{i} \geq \chi_{(0,05 ; p-1)}^{2}$ dari setiap model dan $p$-value dari variabel pada tahap pemilihan model yang cocok, ada dua model yang cocok yaitu model persamaan yang melibatkan semua variabel bebas persamaan (16) dan model persamaan yang melibatkan variabel bebas nafas pasien $\left(X_{6}\right)$, stamina pasien $\left(X_{8}\right)$, dan nafsu makan pasien $\left(X_{9}\right)$ pada persamaan (17). Selanjutnya dilakukan uji partial likelihood antara model pada persamaan (16) dengan model persamaan (17) untuk mengetahui model mana yang dipilih sebagai model akhir Cox. Langkah-langkah uji partial likelihood sebagai berikut:

- Hipotesis

- $H_{0}=\beta_{i}=0$ (model full)

- $H_{1}=\beta_{i} \neq 0$ (model reduce)

- Daerah penolakan : $H_{0}$ ditolak jika $\mathrm{G} \geq \chi_{(0,05 ; 2)}^{2}$ atau $p$ - value $<0,05$,

- $\operatorname{dimana} \mathrm{G}=-2\left(\ln \mathrm{L}_{\mathrm{R}}-\ln \mathrm{L}_{\mathrm{F}}\right)$

- Perhitungan:

- Dari hasil output software SPSS yang selengkapnya diperoleh pada lampiran diperoleh log partial likelihood dari model full yaitu $\ln L_{F}=-210,073$ dan log partial likelihood dari model reduce yaitu $\ln L_{R}=-201,043$.

$$
G=18,06
$$

- Nilai kritis yaitu $\chi_{(0,05 ; 2)}^{2}=5,99$ nilai $p$-value dari uji likelihood tersebut yaitu $P(X \geq 18,06)=0,0036$ untuk df $=3$. Karena $G=18,06 \geq \chi_{(0,1 ; 2)}^{2}$ dan $p$-value $=0,0036$ $<\alpha=0,05$ sehingga $H_{0}$ ditolak, hal ini mengindikasikan bahwa model yang terdiri dari variabel nafas pasien, stamina pasien, dan nafsu makan pasien merupakan model terbaik.

Dengan kata lain bahwa model pada persamaan (17) lebih baik daripada model pada persamaan (16). sehingga model pada persamaan (17) dipilih sebagai model akhir Cox. 


\section{Pengujian Asumsi Proporsional Hazard}

Asumsi terpenting yang harus dipenuhi dalam regresi Cox Proporsional Hazard yaitu asumsi proporsional hazard berarti bahwa rasio fungsi hazard dari dua individu konstan dari waktu ke waktu. Asumsi proporsional hazard terpenuhi apabila garis survival pada kurva Kapplan Meier tidak saling berpotongan.

(a)

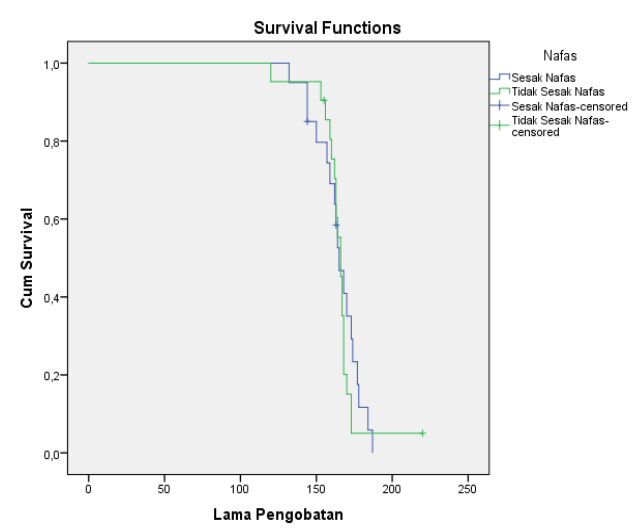

(b)

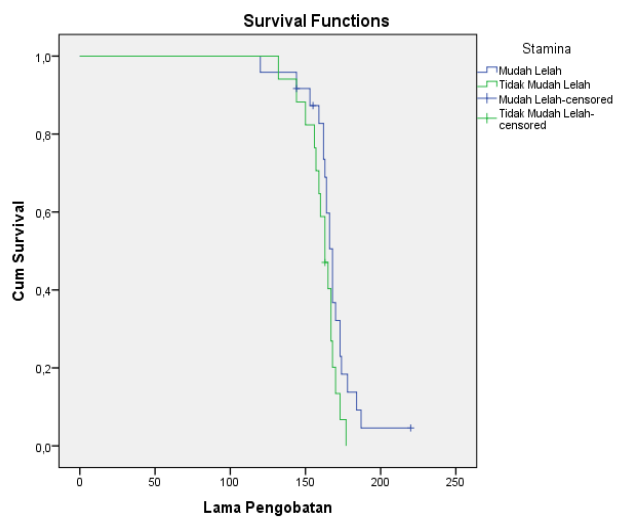

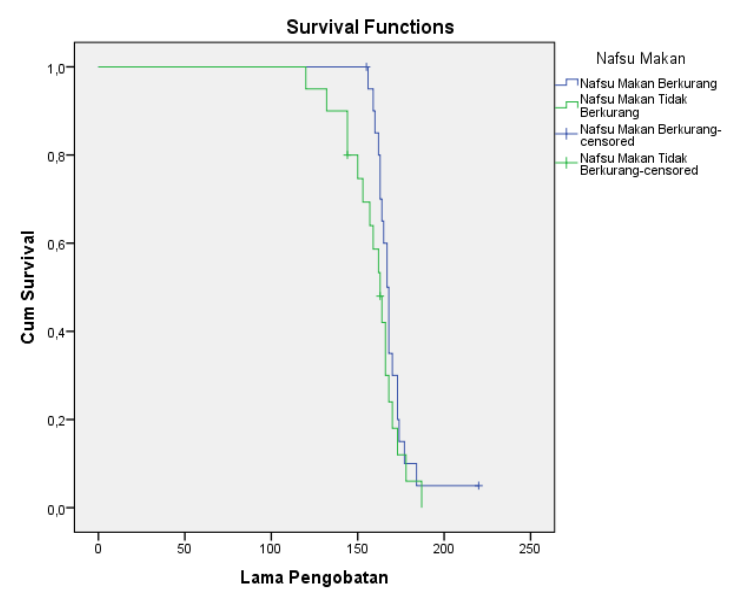

(c)

GAMBAR 2. (a) Kurva Kaplan Meier Untuk Variabel Nafas Pasien, (b) Kurva Kaplan Meier Untuk Variabel Stamina Pasien, (c) Kurva Kaplan Meier Untuk Variabel Nafsu Makan Pasien.

Berdasarkan pengujian asumsi proporsional hazard dengan kurva Kaplan Meier terhadap waktu survival dapat disimpulkan bahwa ketiga variabel tidak memenuhi asumsi proporsional hazard yaitu variabel nafas pasien, stamina pasien, dan nafsu makan pasien.

\section{Model Regresi Cox Non Proporsional Hazard}

Berdasarkan uji asumsi proporsional hazard, maka diperoleh 3 variabel yakni Nafas Pasien, Stamina Pasien, dan Nafsu Makan Pasien yang tidak memenuhi asumsi proporsional hazard. Langkah selanjutnya adalah membuat model cox stratifikasi untuk variabel yang tidak memenuhi asumsi proporsional hazard. Maka dari itu, akan dibentuk model regresi cox non proporsional hazard untuk setiap strata. 
Model Regresi Cox Non Proporsional Hazard Untuk Variabel Nafas Pasien yang Distratakan

TABEL 8. Estimasi Parameter Model Cox Non Proporsional Hazard Dengan Variabel Nafas Pasien Distratakan

\begin{tabular}{ccccc}
\hline Variabel & Koef & SE & p-value & $\operatorname{Exp(Koef)}$ \\
\hline NafsuMakan*Stamina & 0,662 & 0,239 & 0,006 & 1,939 \\
\hline
\end{tabular}

Berdasarkan TABEL 8 diatas, nilai p-value $=0,006<\alpha$, maka model untuk variabel nafas pasien distratakan diterima. Sehingga model regresi cox non proporsional hazard untuk variabel nafas pasien distratakan pada persamaan (21)

$$
h(t, X)=h_{0}(t) \exp \left(0,662\left(X_{6} * X_{8} * X_{9}\right)\right)
$$

Model Regresi Cox Non Proporsional Hazard Untuk Variabel Stamina Pasien yang Distratakan

TABEL 9. Estimasi Parameter Model Cox Non Proporsional Hazard Dengan Variabel Stamina Pasien Distratakan

\begin{tabular}{ccccc}
\hline Variabel & Koef & SE & p-value & $\operatorname{Exp(Koef)}$ \\
\hline Nafas*NafsuMakan & 0,735 & 0,257 & 0,004 & 2,086 \\
\hline
\end{tabular}

Berdasarkan TABEL 9 diatas, nilai $\mathrm{p}$-value $=0,004<\alpha$, maka model untuk variabel stamina pasien distratakan diterima. Sehingga model regresi cox non proporsional hazard untuk variabel stamina pasien distratakan pada persamaan (22)

$$
h(t, X)=h_{0}(t) \exp \left(0,735\left(X_{6} * X_{8} * X_{9}\right)\right)
$$

Model Regresi Cox Non Proporsional Hazard Untuk Variabel Nafsu Makan Pasien yang Distratakan

TABEL 10. Estimasi Parameter Model Cox Non Proporsional Hazard Dengan Variabel Nafsu Makan Pasien Distratakan

\begin{tabular}{ccccc}
\hline Variabel & Koef & SE & p-value & $\operatorname{Exp(Koef)}$ \\
\hline Nafas*Stamina & 0,747 & 0,258 & 0,004 & 2,110
\end{tabular}

Berdasarkan TABEL 10 diatas, nilai $\mathrm{p}$-value $=0,006<\alpha$, maka model untuk variabel nafsu makan pasien distratakan diterima. Sehingga model regresi cox non proporsional hazard untuk variabel nafsu makan pasien distratakan pada persamaan (23)

$$
h(t, X)=h_{0}(t) \exp \left(0,747\left(X_{6} * X_{8} * X_{9}\right)\right)
$$




\section{Interpretasi Model Regresi Cox Non Proporsional Hazard}

Berdasarkan pengujian asumsi proporsional hazard maka model akhir Cox Non Proporsional Hazard sebagai berikut.

$$
\begin{aligned}
& h(t, X)=\frac{\frac{1}{8,578} \frac{e^{-\frac{t-163,88}{8,578}}}{\left(1+e^{-\frac{t-163,88}{8,578}}\right)^{2}}}{1-\left(-\frac{1}{8,578+8,578 e^{-\frac{t-163,88}{8,578}}}\right)} \exp \left(0,662\left(X_{6} * X_{8} * X_{9}\right)\right) \\
& h(t, X)=\frac{\frac{1}{8,578} \frac{e^{-\frac{t-163,88}{8,578}}}{\left(1+e^{-\frac{t-163,88}{8,578}}\right)^{2}}}{1-\left(-\frac{1}{8,578+8,578 e^{-\frac{t-163,88}{8,578}}}\right)} \exp \left(0,735\left(X_{6} * X_{8} * X_{9}\right)\right) \\
& h(t, X)=\frac{\frac{1}{8,578} \frac{e^{-\frac{t-163,88}{8,578}}}{\left(1+e^{-\frac{t-163,88}{8,578}}\right)^{2}}}{1-\left(-\frac{1}{8,578+8,578 e^{-\frac{t-163,88}{8,578}}}\right)} \exp \left(0,747\left(X_{6} * X_{8} * X_{9}\right)\right)
\end{aligned}
$$

dimana:

$X_{6} \quad$ : Nafas Pasien

$X_{8} \quad$ : Stamina Pasien

$X_{9} \quad$ : Nafsu Makan Pasien

Untuk mengetahui laju kesembuhan pasien dapat dicari berdasarkan odds rasio variabel-variabel yang signifikan seperti yang terlihat pada TABEL 11 berikut ini:

TABEL 11. Estimasi Parameter Model Regresi Cox Non Proporsional Hazard Dengan Tiga Variabel Yang Signifikan

\begin{tabular}{lcccc}
\hline \multicolumn{1}{c}{ Variabel } & Koefisien & SE & p-value & $\begin{array}{c}\text { Odds Rasio }= \\
\text { Exp(Koefisien) }\end{array}$ \\
\hline NafsuMakan*Stamina & 0,662 & 0,239 & 0,006 & 1,939 \\
Nafas*NafsuMakan & 0,735 & 0,257 & 0,004 & 2,086 \\
Nafas*Stamina & 0,747 & 0,258 & 0,004 & 2,110 \\
\hline
\end{tabular}

12. Laju Kesembuhan Pasien berdasarkan Nafas Pasien

Dari TABEL 11, dapat diperoleh koefisien nafas pasien sebesar 0,662 yang menunjukkan bahwa pasien yang tidak mengalami sesak nafas memiliki risiko untuk sembuh sebesar 1,939 kali dibandingkan dengan pasien yang mengalami sesak nafas. Sehingga, dapat disimpulkan bahwa pasien yang mengalami sesak nafas laju kesembuhannya semakin lama.

13. Laju Kesembuhan Pasien berdasarkan Stamina Pasien

Dari TABEL 11, dapat diperoleh koefisien stamina pasien sebesar 0,735 yang menunjukkan bahwa pasien yang tidak mengalami mudah lelah memiliki risiko untuk sembuh sebesar 2,086 kali dibandingkan dengan pasien yang mengalami mudah lelah. Sehingga, dapat disimpulkan bahwa pasien yang mengalami mudah lelah laju kesembuhannya semakin lama. 
14. Laju Kesembuhan Pasien berdasarkan Nafsu Makan Pasien

Dari TABEL 11, dapat diperoleh koefisien nafsu makan pasien sebesar 0,747 yang menunjukkan bahwa pasien yang tidak mengalami berkurangnya nafsu makan memiliki risiko untuk sembuh sebesar 2,110 kali dibandingkan dengan pasien yang mengalami berkurangnya nafsu makan. Sehingga, dapat disimpulkan bahwa pasien yang mengalami berkurangnya nafsu makan laju kesembuhannya semakin lama.

\section{KESIMPULAN}

Berdasarkan hasil penelitian dan pembahasan mengenai metode regresi cox non proporsional hazard dalam penentuan faktor-faktor yang berpengaruh terhadap laju kesembuhan pasien penderita Tuberkulosis, maka dapat disimpulkan sebagai berikut:

Variabel yang berpengaruh secara signifikan terhadap laju kesembuhan pasien penderita tuberkulosis di Balai Besar Kesehatan Paru Masyarakat Makassar sebanyak 3 variabel yakni nafas pasien, stamina pasien, dan nafsu makan pasien. Hal tersebut mengindikasikan bahwa:

- Laju kesembuhan pasien berdasarkan nafas pasien dapat diperoleh bahwa risiko ketika pasien mengalami sesak nafas untuk sembuh sebesar 1,939 kali dibandingkan dengan pasien yang tidak mengalami sesak nafas. Sehingga, dapat disimpulkan bahwa pasien yang mengalami sesak nafas laju kesembuhannya semakin lama.

- Laju kesembuhan pasien berdasarkan stamina pasien dapat diperoleh bahwa risiko ketika pasien mengalami mudah lelah untuk sembuh sebesar 2,086 kali dibandingkan dengan pasien yang tidak mengalami mudah lelah. Sehingga, dapat disimpulkan bahwa pasien yang mengalami mudah lelah laju kesembuhannya semakin lama.

- Laju kesembuhan pasien berdasarkan nafsu makan pasien dapat diperoleh bahwa risiko ketika pasien mengalami berkurangnya nafsu makan untuk sembuh sebesar 2,110 kali dibandingkan dengan pasien yang tidak mengalami berkurangnya nafsu makan. Sehingga, dapat disimpulkan bahwa pasien yang mengalami berkurangnya nafsu makan laju kesembuhannya semakin lama.

\section{DAFTAR PUSTAKA}

Ernawatiningsih, N.P.L. \& Purhadi. (2012). Analisis Survival Model Regresi Cox..Jurnal Matematika, 2(2). 25-32

Kleinbaum,D.G. \& Klein, M. (2005). Survival Analysis: A Self-Learning Text. New York: Springer.

Habriantho, A. (2016). Model Cox Stratifikasi. Universitas Negeri Makassar, Makassar.

Wikipedia. (2014). Tuberkulosis. http://id.wikipedia.org/wiki/Tuberkulosis/2014 . diakses tanggal 20 Mei 2016.

Dinkes Makassar. (2013). Profil Kesehatan Kota Makassar 2013. http://dinkeskotamakassar.net/download/718Gabung\%20profil\%202013.pdf . diakses tanggal 20 Mei 2016.

Kleinbaum, D.G. \& Klein, M. (2011). Survival Analysis. New York: Springer.

Klein, J.P. \& Moeschberger, M.L. (1997). Survival Analysis Technique for Censored and Truncated Data. New York: Springer. 
Rahayu, N., Setiawan, A., \& Mahatma, T. (2012). Analisis Regresi Cox Proportional Hazards pada Ketahanan Hidup Pasien Diabetes Mellitus. Seminar Nasionanal Matematika 2012, (196-206). Salatiga, Indonesia: Universitas Kristen Satya Wacana.

Sari, D.R. (2011). Analisis Suevival Untuk Data Tersensor Tipe II Menggunakan Model Distribusi Log-Logistik. Universitas Negeri Yogyakarta,Yogyakarta.

Hanni, T. \& Wuryandari,T. (2013). Model Regresi Cox Proporsional Hazard Pada Data Ketahanan Hidup. Media Statistika, 6(1). 11-20.

Fa'rifah, R.Y. \& Purhadi. (2012). Analisis Survival Faktor-Faktor yang Mempengaruhi Laju Kesembuhan Pasien Penderita Demam Berdarah Dengue (DBD) RSU Haji Surabaya dengan Regresi Cox. Jurnal Sains dan Seni ITS ,1(1).

Hosmer, D.W. \& Lemeshow, S. (1997). Applied Survival Analysis Regression Modelling of Time to Event Data. New York: John Wlley and Sons, Inc.

Febriyanti,A., Yozza, H., \& Rahmi H.G.I. (2013). Penerapan Metode Multivariate Adaptive Regression Spline (MARS) Untuk Mengidentifikasi Komponen Yang Berpengaruh Terhadap Peringkat Akreditasi Sekolah. Jurnal Matematika UNAND, 2(2). 44-53.

Cahyani,T. P., Subanti, S., \& Widyaningsih, P. (2014). Analisis Tahan Hidup Penderita Demam Berdarah Dengue (DBD) Di Kabupaten Karanganyar Dengan Pendekatan Bayesian. Universitas Sebelas Maret, Surakarta.

Nurhaniah. (2015). Pendekatan Regresi Cox Proporsional Hazard dalam Penentuan FaktorFaktor yang Berpengaruh terhadap Lama Studi Mahasiswa S-1 Matematika di Universitas Negeri Makassar..Universitas Negeri Makassar, Makassar.

Kapadia, A. S., Chan, W., \& Moye, L. A. (2005). Mathematical Statistics with Applications. Boca Raton: Chapman \& Hall/CRC Taylor \& Francis Group. 